\title{
Reproductive effects of sulfoxaflor in male Sprague Dawley rats
}

\author{
Wafaa H. Mohamed ${ }^{1}$ - Marwa F. Ali ${ }^{2}$ - Doha Yahia ${ }^{3} \cdot$ Hassan A. Hussein ${ }^{4}$
}

Received: 27 August 2021 / Accepted: 28 January 2022 / Published online: 11 February 2022

(c) The Author(s) 2022

\begin{abstract}
The study objective was to evaluate the potential reproductive toxicity of sulfoxaflor (SFX) insecticide in male Sprague Dawley rats. To attain these objectives, forty male Sprague Dawley rats of 10-12 weeks old were randomly divided into four equal groups; the 1st group was used as a control group; the other three groups were exposed to 25, 100, and $500 \mathrm{mg}$ / $\mathrm{kg}$ body weight SFX by oral gavage for 4 weeks. Relative testicular weight, testosterone, FSH, LH, MDA, and GPx levels, sperm viability, sperm morphology, sperm DNA damage, and histopathological changes in testes, epididymis, and seminal vesical of these rats were investigated after 4 weeks. The results showed that SFX exposure resulted in a significant increase in FSH, LH, MDA, and GPx levels as well as the percentage of dead and abnormal sperms and DNA damage in rat sperms. Histopathological examination of testes established testicular degeneration with coagulative necrosis as well as the proliferation of interstitial connective tissue infiltrated with inflammatory cells with congestion of intertubular blood vessels in epididymis and degeneration of lining epithelium of seminal vesicles.
\end{abstract}

Keywords Sulfoxaflor $\cdot$ Reproductive toxicity $\cdot$ Sperm viability $\cdot$ Sperm morphology and sperm DNA damage

\section{Introduction}

The use of pesticides in global agriculture is uncontrolled and poses a huge threat to public health. Many investigations have revealed that the presence of the residues of pesticides in soil, water, and agricultural products can affect humans and can enter to the bloodstream and bind to circulating serum proteins (Hadi Chegni et al. 2020). Insect resistance to the existing insecticides is a big problem and has cost billions of dollars in the agricultural field and could result in many insect-vectored diseases (Gould et al. 2018). Although many species of insect are controlled by neonicotinoids, but

Responsible Editor: Mohamed M. Abdel-Daim

Wafaa H. Mohamed

wafaavet96@yahoo.com

1 Department of Forensic Medicine and Toxicology, Faculty of Veterinary Medicine, Aswan University, Aswan, Egypt

2 Department of Veterinary Pathology and Clinical Pathology, Faculty of Veterinary Medicine, Assiut University, Assiut, Egypt

3 Department of Forensic Medicine and Toxicology, Faculty of Veterinary Medicine, Assiut University, Assiut, Egypt

4 Department of Theriogenology, Faculty of Veterinary Medicine, Assiut University, Assiut, Egypt their extensive use has led to the presence of resistance in some pests as sap-feeding insects (Bass and Field 2018). Sulfoximine is a relatively recent insecticidal designed to control of sap-feeding insects (Watson et al. 2021). Sulfoxaflor (SFX) is the first compound in this category and was selected for commercial development. Sulfoximine (SFX) acts on nicotinic acetylcholine receptors (nAChRs) in insects and it functions in a different mode from other insecticides acting at nAChRs (Sparks et al. 2020). It belongs to the fourth generation of neonicotinoid; it has been regarded as subgroup 4C by the Insecticide Resistance Action Committee (IRAC) due to its sulfoximine structure and low insecticidal resistance (Xu et al. 2020).

Its residues would stay in the plants, water, and soil for many days after treatment; therefore, the toxicity of SFX may increase due to its long-term bioaccumulation through the food chain (Xu et al. 2020). In spite of the fact that SFX has more advantages than other insecticides, it can alter nicotinic acetylcholine receptors, causing neurotoxicity (Authority et al. 2019) and induced liver effects as hepatocellular hypertrophy and liver tumors in rats and mice (Bacci et al. 2018), although several studies reported the toxic effects of different neonicotinoids on animals and humans, such as hepatotoxicity, neurotoxicity, and immunotoxicity (Fathy and Abdelkader 2021a; Piner Benli and Çelik 
2021b). However, the reproductive effects of SFX have not been evaluated; yet, therefore, the goal of the current study is to investigate the impact of sulfoxaflor on the reproductive system of Sprague Dawley rats.

\section{Materials and methods}

\section{Chemicals}

A commercial formulation of SFX (Dow AgroSciences Company, Canada) as a suspension containing $24 \%$ (w/w) sulfoxaflor as an active ingredient, sodium carbonate (El Nasr Pharmaceutical Chemicals Co., Egypt), methyl violet, eosin, and nigrosin stain (S. D Fine-Chem Limited, India). All chemicals and reagents were of the highest level of purity.

\section{Animals}

A total of 40 male Sprague Dawley rats (10-12 weeks old weighing $120-150 \mathrm{~g}$ ) were purchased from the Animal House, Faculty of Medicine, Assiut University. Rats were kept in plastic cages that contained five rats each. Animals were kept for 2 weeks before the experiment for acclimatization. Feed and drinking water were administered ad libitum. Rats were maintained at a temperature of $22 \pm 2{ }^{\circ} \mathrm{C}$, and a lighting period of $12 \mathrm{~h}$ (light/dark). The handling of laboratory animals was carried out in accordance with the international guidelines of the National Research Council (NRC 1996). Protocols of the study were approved by the ethical committee of the Faculty of Veterinary Medicine, Assiut University, Egypt (March, 2021).

\section{Experimental design}

Forty rats were divided into four groups of 10 animals each:

Group I Control group, rats were given distilled water $1 \mathrm{ml} / 100 \mathrm{~g}$ orally using stomach tube day by day for 4 weeks.

Group II Rats were exposed to SFX (dissolved in distilled water) at a dose rate $25 \mathrm{mg} / \mathrm{kg}$ body weight by oral gavage, day by day for 4 weeks. This dose is $1 / 40$ of the oral $\mathrm{LD}_{50}$ of SFX (1000 mg/kg body weight) as reported by FAO/WHO (2003).

Group III Rats were administered SFX at a dose rate $100 \mathrm{mg} / \mathrm{kg}$ body weight which was $1 / 10 \mathrm{LD}_{50}$ by oral gavage, day by day for 4 weeks.

Group IV Rats were dosed SFX at a dose rate $500 \mathrm{mg} / \mathrm{kg}$ body weight which was $1 / 2 \mathrm{LD}_{50}$ by oral gavage, day by day for 4 weeks.

\section{Samples collection}

At the end of the experiment, ten rats from each group were euthanized by diethyl ether anesthesia for samples collection. Blood samples were collected from the descending aorta into sterile test tubes without anticoagulants. Serum was obtained after centrifugation at $3000 \mathrm{rpm}$ for $10 \mathrm{~min}$. The serum samples were kept at $-20^{\circ} \mathrm{C}$ to estimate testosterone, $\mathrm{FSH}$, and $\mathrm{LH}$ hormones levels and evaluate oxidative status by measuring malondialdehyde (MDA) and glutathione peroxidase (GPx). The caudal part of the epididymis was cut and transferred into petri dish containing drops of normal saline at $37{ }^{\circ} \mathrm{C}$ then a few drops of sperm suspension were taken to evaluate the viability, morphology, and DNA integrity of sperms. For histopathological examination, samples from testes, epididymis, and seminal vesical were fixed in $10 \%$ formaldehyde, dehydrated, and embedded in paraffin then sections were cut and stained with hematoxylin and eosin (H\&E) (Suvarna et al. 2018).

\section{Organosomatic index of testes}

The total body weight and testicular weight were determined and the testicular organosomatic index was calculated (testicular weight/ body weight).

\section{Hormonal assays}

\section{Serum testosterone levels}

The concentration of serum testosterone was estimated at wavelength $450 \mathrm{~nm}$ according to the method of Tietz (1995) using a testosterone ELISA test kit (Biodiagnostic, Egypt) by ELISA reader apparatus (Bio-Tec instrument).

\section{Serum follicle stimulating hormone levels}

Levels of serum FSH were determined according to Scott et al. (1989) at 490-630 nm using an enzyme immunoassay test kit which was obtained from Biodiagnostic, Egypt. ELISA reader apparatus used is Bio-Tec instrument.

\section{Serum luteinizing hormone levels}

Serum LH levels were estimated according to Beastall et al. (1987) at 490-630 nm using an enzyme immunoassay test kit which was purchased from Biodiagnostic, Egypt. ELISA reader apparatus used is Bio-Tec instrument.

\section{Estimation of serum MDA level and GPx activity}

MDA level was measured at $534 \mathrm{~nm}$ by the method as described by ohkawa et al. (1979). However, GPx activity 
was estimated at $340 \mathrm{~nm}$ according to the method of Paglia and Valentine (1967) using commercial kits (Biodiagnostic, Egypt) and through a spectrophotometer (UV-2100 spectrophotometer, Unico, USA).

\section{Evaluation of epididymal sperm parameters}

\section{Sperm viability test}

To estimate sperm viability percentage, the cauda epididymal duct was exposed and incised; the semen that oozed was diluted $200(0.05 \mu \mathrm{L}$ of sperm with $99.95 \mu \mathrm{L}$ of PBS $)$ times in physiological saline. In a sterile test tube, $20 \mu \mathrm{L}$ of sperm suspension was put with $20 \mu \mathrm{L}$ of $0.05 \%$ eosinY. After $20 \mathrm{~s}, 50 \mu \mathrm{L}$ of nigrosin was mixed thoroughly with them. The mixture of stained sperm was smeared on the slide and examined under a light microscope (Olympus BX 43, Japan) at $\times 100$. For each slide, a total of 200 sperm cells were examined. Dead sperms were pink and live sperms were not stained. This method was described by Wyrobek et al. (1983).

\section{Sperm morphology test}

The percentage of morphologically abnormal spermatozoa was determined according to the method of Menkveld (2010). The sample was diluted with $1 \%$ sodium chloride solution. After thoroughly mixing, one drop of sperm suspension was smeared on a slide. Dried in the air and stained immediately with one part of a $1 \%$ sodium carbonate solution is mixed thoroughly with nine parts of $1 \%$ the methyl-violet solution immediately before use. The stain was left for 4 to $5 \mathrm{~min}$. The preparation was then washed with distilled water. The slide dried with filter paper and sperm cells were examined under a light microscope at $\times 100$ magnification.

\section{Assessment of sperm DNA damage}

A small drop of the sperm suspension was smeared on the glass slides. The slides were dried in air and fixed in Carnoy's solution (methanol/acetic acid, 3:1) for $2 \mathrm{~h}$. The slides were stained for $5 \mathrm{~min}$ with freshly prepared acridine orange solution $(19.00 \%)$ in phosphate citrate. The slides were washed with deionized water, then examined using a fluorescent microscope (Olympus BX43, Japan) equipped with a blue filter. Two hundred sperms were examined on each slide. Sperm heads with intact chromatin had green fluorescence, while those with denatured chromatin had orange-red staining (Tejada et al. 1984).

\section{Histopathological investigation}

Fresh specimens from testes, epididymides, and seminal vesicles of rats of all experimental groups were collected and fixed in $10 \%$ neutral buffered formalin. Tissue samples were processed routinely, sectioned at $4 \mu \mathrm{m}$ thickness, and stained with hematoxylin and eosin (H\&E) for histopathological examination by light microscopy (Olympus, CX31; Tokyo Japan) and photographed using a digital camera (Toupview, LCMos 10000KPA, China) (Suvarna et al. 2018). The microscopic findings for each group were presented in a table to demonstrate the type of lesion, severity, and percentage of animals according to Sayed et al. (2014).

\section{Data analysis}

The results were presented as mean \pm SE. One-way analysis of variance (ANOVA) was used followed by post hoc test (Tukey) to detect a significant difference among groups. These analyses were conducted using the SPSS program for Windows, version 16.0 (Borenstein et al. 1997). Differences between and among the groups were considered significant at $p \leq 0.05$.

\section{Results}

No death occurred in any experimental group throughout the experiment.

\section{Testicular somatic index}

The relative testicular weight did not show significant changes in the exposed groups in comparison with the control group (Table 1).

\section{Hormonal assays (serum testosterone, FSH, and LH levels)}

Testosterone level in serum did not illustrate any significant change at any dose when compared to the control group. After 4 weeks of treatment, SFX at $500 \mathrm{mg} / \mathrm{kg}$ caused a

Table 1 Testicular organosomatic index in rats after oral administration of SFX $(25,100$ and $500 \mathrm{mg} / \mathrm{kg} / \mathrm{b}$.w.) for 4 weeks

\begin{tabular}{ll}
\hline Groups & $\begin{array}{l}\text { Testicular } \\
\text { organosomatic } \\
\text { index }\end{array}$ \\
\hline Control & $2.140 \pm 0.133$ \\
$25 \mathrm{mg} / \mathrm{kg} \mathrm{SFX}$ & $1.875 \pm 0.094$ \\
$100 \mathrm{mg} / \mathrm{kg} \mathrm{SFX}$ & $1.655 \pm 0.194$ \\
$500 \mathrm{mg} / \mathrm{kg} \mathrm{SFX}$ & $1.382 \pm 0.330$ \\
\hline
\end{tabular}


Table 2 Testosterone, FSH, and LH hormones levels in rats after oral administration of SFX $(25$, 100 , and $500 \mathrm{mg} / \mathrm{kg} / \mathrm{b} . \mathrm{w}$.) for 4 weeks

\begin{tabular}{llll}
\hline Groups & Testosterone $(\mathrm{ng} / \mathrm{mL})$ & $\begin{array}{l}\text { FSH } \\
(\mu \mathrm{l} \mathrm{U} / \mathrm{mL})\end{array}$ & $\begin{array}{l}\mathrm{LH} \\
(\mu \mathrm{l} \mathrm{U} / \mathrm{mL})\end{array}$ \\
\hline Control & $3.150 \pm 0.144$ & $0.250 \pm 0.005$ & $1.510 \pm 0.017$ \\
$25 \mathrm{mg} / \mathrm{kg} \mathrm{SFX}$ & $3.266 \pm 0.290$ & $0.270 \pm 0.015$ & $1.636 \pm 0.080$ \\
$100 \mathrm{mg} / \mathrm{kg} \mathrm{SFX}$ & $3.400 \pm 0.173$ & $0.326 \pm 0.035$ & $1.776 \pm 0.054 \mathrm{ac}^{*}$ \\
$500 \mathrm{mg} / \mathrm{kg} \mathrm{SFX}$ & $3.686 \pm 0.121$ & $0.426 \pm 0.027 \mathrm{a} * \mathrm{~b}^{*}$ & $2.110 \pm 0.017 \mathrm{a}^{*} \mathrm{~b}^{*} *$ \\
\hline
\end{tabular}

Values were expressed as means $\pm \mathrm{SE}(n=10)$. * indicates highly significant at $p \leq 0.01$; a indicates significance at $p \leq 0.05$ in comparison with the control group; b indicates significance at $p \leq 0.05$ in comparison with $25 \mathrm{mg} / \mathrm{kg}$ dose group; $c$ indicates significance at $p \leq 0.05$ between 100 and $500 \mathrm{mg} / \mathrm{kg}$ dose groups
Table 3 MDA level and GPx activity in rats exposed to 25, 100, and $500 \mathrm{mg} / \mathrm{kg} / \mathrm{b}$.w.of SFX for 4 weeks

\begin{tabular}{lll}
\hline Groups & $\begin{array}{l}\text { MDA } \\
\text { (nanomole/mg protein) }\end{array}$ & $\begin{array}{l}\text { GPx } \\
(\mathrm{U} / \mathrm{mL})\end{array}$ \\
\hline Control & $0.220 \pm 0.011$ & $117 \pm 1.154$ \\
$25 \mathrm{mg} / \mathrm{kg} \mathrm{SFX}$ & $0.365 \pm 0.008 \mathrm{a}^{*}$ & $130 \pm 1.154$ \\
$100 \mathrm{mg} / \mathrm{kg} \mathrm{SFX}$ & $0.396 \pm 0.018 \mathrm{a}^{*} \mathrm{c}^{*}$ & $246 \pm 5.773 \mathrm{a}^{*} \mathrm{~b}^{*} \mathrm{c}^{*}$ \\
$500 \mathrm{mg} / \mathrm{kg} \mathrm{SFX}$ & $0.523 \pm 0.026 \mathrm{a}^{*} \mathrm{~b}^{*} \mathrm{c}^{*}$ & $306 \pm 4.618 \mathrm{a}^{*} \mathrm{~b}^{*} \mathrm{c}^{*}$ \\
\hline
\end{tabular}

Values were expressed as means $\pm \operatorname{SE}(n=10)$. * indicates highly significant at $p \leq 0.01$; a indicates significance at $p \leq 0.05$ in comparison with the control group; $\mathrm{b}$ indicates significance at $p \leq 0.05$ in comparison with $25 \mathrm{mg} / \mathrm{kg}$ dose group; c indicates significance at $p \leq 0.05$ between 100 and $500 \mathrm{mg} / \mathrm{kg}$ dose groups

significant $(P<0.01)$ increase in FSH level in comparison with the control and $25 \mathrm{mg} / \mathrm{kg}$ dose groups, while LH level significantly increased in SFX-exposed groups to $100 \mathrm{mg} / \mathrm{kg}$ $(P<0.05)$ and $500 \mathrm{mg} / \mathrm{kg}(P<0.01)$ as compared with the control group and SFX at $500 \mathrm{mg} / \mathrm{kg}$ showed a significant $(P<0.01)$ increase as compared with $25 \mathrm{mg} / \mathrm{kg}$ group. Also, there was a significant $(P<0.01)$ increase in LH level in rats exposed to $500 \mathrm{mg} / \mathrm{kg}$ in comparison with rats exposed to $100 \mathrm{mg} / \mathrm{kg}$ (Table 2).

\section{MDA level and GPx activity}

The level of MDA significantly $(P<0.01)$ increased in all SFX-exposed groups as compared with the control group, while $500 \mathrm{mg} / \mathrm{kg}$ group revealed a significant $(P<0.01)$ increase in comparison with 25 and $100 \mathrm{mg} / \mathrm{kg}$ dose groups.
GPx activity illustrated a significant $(P<0.01)$ increase in 100 and $500 \mathrm{mg} / \mathrm{kg}$ dose groups as compared with the control group and $25 \mathrm{mg} / \mathrm{kg}$ dose group. However, GPx in rats exposed to $500 \mathrm{mg} / \mathrm{kg}$ SFX showed a significant $(P<0.01)$ increase when compared with $100 \mathrm{mg} / \mathrm{kg}$ dose group (Table 3).

\section{Sperm parameters}

The percentage of dead epididymal sperm showed a significant increase at $25(P<0.05), 100$ and $500 \mathrm{mg} / \mathrm{kg}$ doses $(P<0.01)$ groups as compared with the control group. Also, 100 and $500 \mathrm{mg} / \mathrm{kg}$ SFX dose groups revealed a significant $(P<0.01)$ increase as compared with $25 \mathrm{mg} / \mathrm{kg}$ dose group. However, there is a significant $(P<0.01)$ increase in $500 \mathrm{mg} /$ $\mathrm{kg}$ SFX dose group in comparison with $100 \mathrm{mg} / \mathrm{kg}$ dose group (Figs. 1 and 3). The percentage of abnormal sperms significantly $(P<0.01)$ increased in all SFX-exposed groups as compared with the control group, while 100 and $500 \mathrm{mg} /$ $\mathrm{kg}$ dose groups showed a significant $(P<0.01)$ increase in comparison with the $25 \mathrm{mg} / \mathrm{kg}$ dose group (Figs. 2 and 3). The percentage of DNA damage in sperms of rats in the $500 \mathrm{mg} / \mathrm{kg}$ dose group indicated a significant $(P<0.01)$ increase in comparison with control, 25 , and $100 \mathrm{mg} / \mathrm{kg}$ doses groups (Table 4) (Figs. 3 and 4).

\section{Histopathological examination}

Histopathological changes in all SFX-exposed groups are presented in Figs. 5-9 and Table 5. Microscopic examination of testes in the control rats showed normal structure
Fig. 1 A Eosine nigrosinstained semen film of control rats showed normal live epididymal sperm, not stained (arrow). B Semen film of SFX-treated rats showed dead epididymal sperms (appeared pink) (arrow) $(\times 40)$
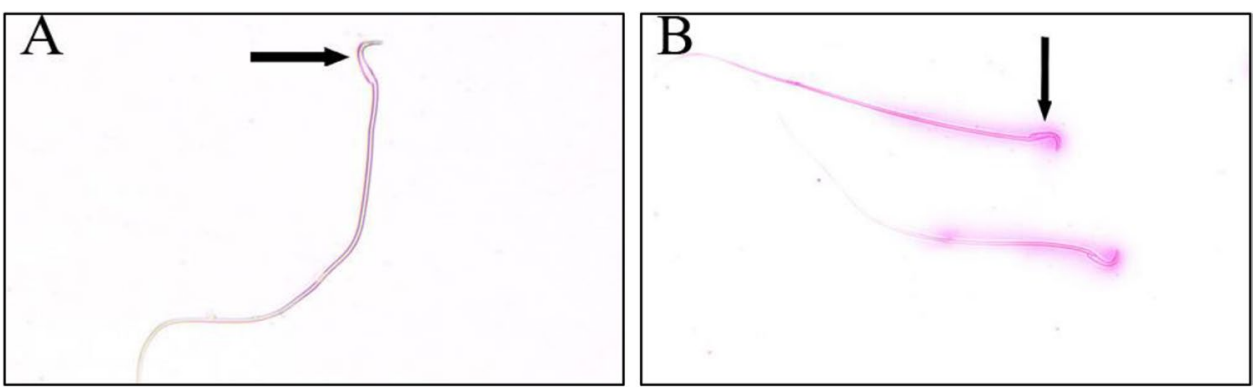
Fig. 2 Photos of methyl violet stained semen film of control and SFX-treated rats showing epididymal sperms morphology. (A) Normal sperm, (B) detached head, $(\mathbf{C})$ broken tail, (D) microcephalic head, (E) double head with a single tail, and $(\mathbf{F})$ coiled tail $(\times 40)$

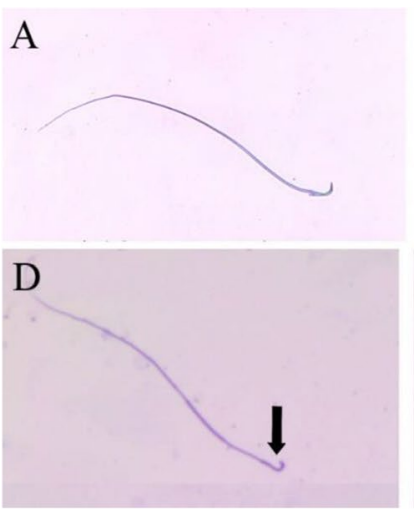

B
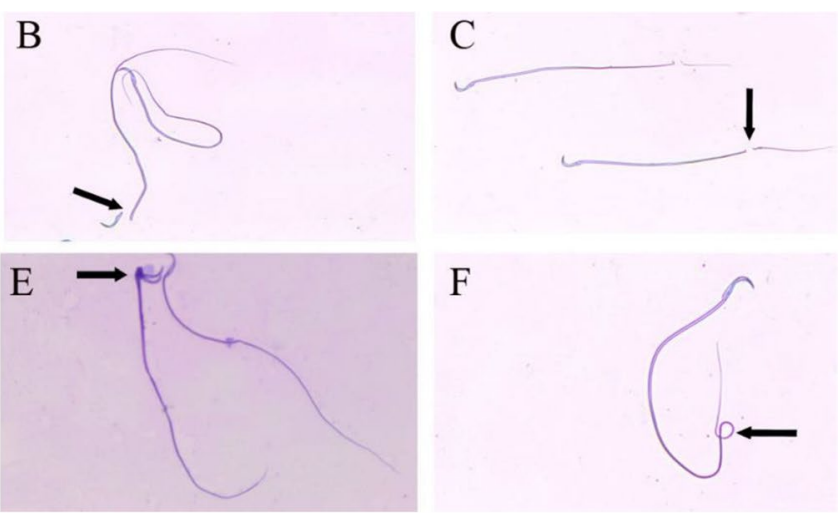

Table 4 The percentage of intact and damaged sperms of rats exposed to 25,100 , and $500 \mathrm{mg} / \mathrm{kg} / \mathrm{b}$.w.of SFX for 4 weeks

\begin{tabular}{lcc}
\hline Groups & Intact sperm (\%) & Damaged sperm (\%) \\
\hline Control & $100 \pm 0.000$ & $0.000 \pm 0.000$ \\
$25 \mathrm{mg} / \mathrm{kg} \mathrm{SFX}$ & $100 \pm 0.000$ & $0.000 \pm 0.000$ \\
$100 \mathrm{mg} / \mathrm{kg} \mathrm{SFX}$ & $98.666 \pm 0.333 \mathrm{c} *$ & $1.333 \pm 0.333 \mathrm{c} *$ \\
$500 \mathrm{mg} / \mathrm{kg} \mathrm{SFX}$ & $90.000 \pm 1.732 \mathrm{a} * \mathrm{~b} * \mathrm{c} * 10.000 \pm 1.732 \mathrm{a} * \mathrm{~b} * \mathrm{c} *$ \\
\hline
\end{tabular}

Values were expressed as means $\pm \mathrm{SE}(n=10)$. * indicates highly significant at $p \leq 0.01$; a indicates significance at $p \leq 0.05$ in comparison with the control group; $\mathrm{b}$ indicates significance at $p \leq 0.05$ in comparison with $25 \mathrm{mg} / \mathrm{kg}$ dose group; c indicates significance at $p \leq 0.05$ between 100 and $500 \mathrm{mg} / \mathrm{kg}$ dose groups

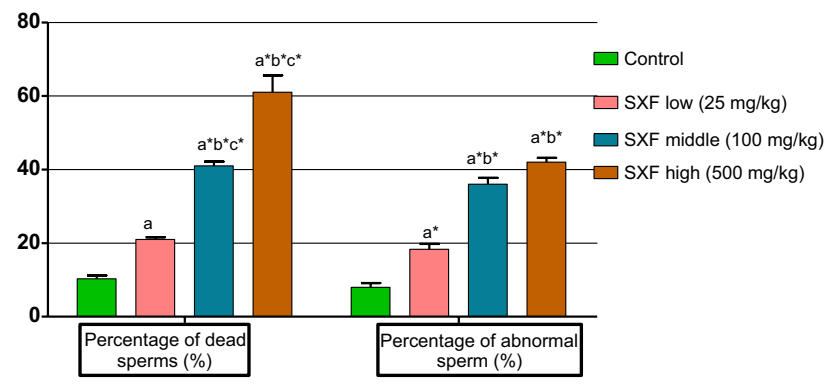

Fig. 3 The effect of SFX on sperm viability and morphology in male rats exposed to 25,100 , and $500 \mathrm{mg} / \mathrm{kgb}$.w. of SFX for 4 weeks. * indicates highly significance at $p \leq 0.01$; a indicates significance at $p \leq 0.05$ in comparison with the control group; b Indicates significance at $p \leq 0.05$ in comparison with $25 \mathrm{mg} / \mathrm{kg}$ dose group; c indicates significance at $p \leq 0.05$ between 100 and $500 \mathrm{mg} / \mathrm{kg}$ dose groups

of seminiferous tubules lined by normal germinal epithelium composed of maturing germ cells (spermatogonia, spermatocytes, spermatids, and spermatozoa) and Sertoli cells resting on the basement membrane (Fig. 5A, B, \& C). While the histopathological examination of testes in the $25 \mathrm{mg} / \mathrm{kg}$ SFX exposed group showed the accumulation of tissue debris with testicular degeneration in the germinal epithelium causing decrease in the number of layers in the lining epithelium in a small number of seminiferous tubules (Fig. 5D). Dilatation of seminiferous tubules was also noticed in other tubules, characterized by a necrosis in the lining germinal epithelium with an increased luminal diameter of the seminiferous tubules filled with oedematous fluid (Fig. 5E). Exposure to $100 \mathrm{mg} / \mathrm{kg}$ SFX induced obvious damage in the testes of the rats. This damage characterized by testicular degeneration appeared in most seminiferous tubules with the appearance of multinucleated giant cells in the tubular lumen associated with a decrease in the number of layers of germinal epithelium lining of seminiferous tubules (Fig. 5F). Another pattern of the testicular deformity was necrosis in most layers of the germinal epithelium with hypereosinophilic, vacuolized, disorganized cells showing pyknosis of nucleoli accompanied with the formation of (spermatid giant cells) (Fig. 5G). Additionally, interstitial oedema with mild hyperplasia of (leydig cells) was seen in $75 \%$ of rats, in a focal manner (Fig. $5 \mathrm{H}$ ). Dilatation of seminiferous tubules with necrosis of the germinal epithelium was seen in sporadic seminiferous tubules (Fig. 5I). Rats exposed to $500 \mathrm{mg} / \mathrm{kg}$ SFX showed evident histopathological alterations. Coagulative necrosis in germinal epithelium of the seminiferous tubules with absence of mature sperms in the lumen was noticed in many tubules (Fig. 5J). Detachment of germinal epithelium with dilatation of seminiferous tubules was filled with eosinophilic fluid with the appearance of multinucleated giant cells (Fig. 5K). Congestion of interstitial blood vessels with hyperplasia of Leydig cells also was seen in testes of rats in this group (Fig. 5L).

Histological examination of the epididymides in control rats showed an epididymal convoluted tubule lined with pseudostratified columnar epithelium (Fig. 6A\&B). The changes of epididymis in the $25 \mathrm{mg} / \mathrm{kg} \mathrm{SFX}$-intoxicated group included decrease in the number of sperms inside the lumen of epididymal ducts (Fig. 6C); proliferation of interstitial connective tissue with congestion of intertubular blood vessels were observed in the epididymis of this group (Fig. 6D). Microscopic examination of epididymal sections in the $100 \mathrm{mg} / \mathrm{kg}$ SFX-intoxicated group revealed that all examined rats exhibited obvious changes. These 
Fig. 4 A Acridine orangestained semen film of SFXexposed rats showed damaged sperm DNA (yellow head). B Semen film of control rats showed normal intact sperm DNA (appeared green head) $(\times 40)$
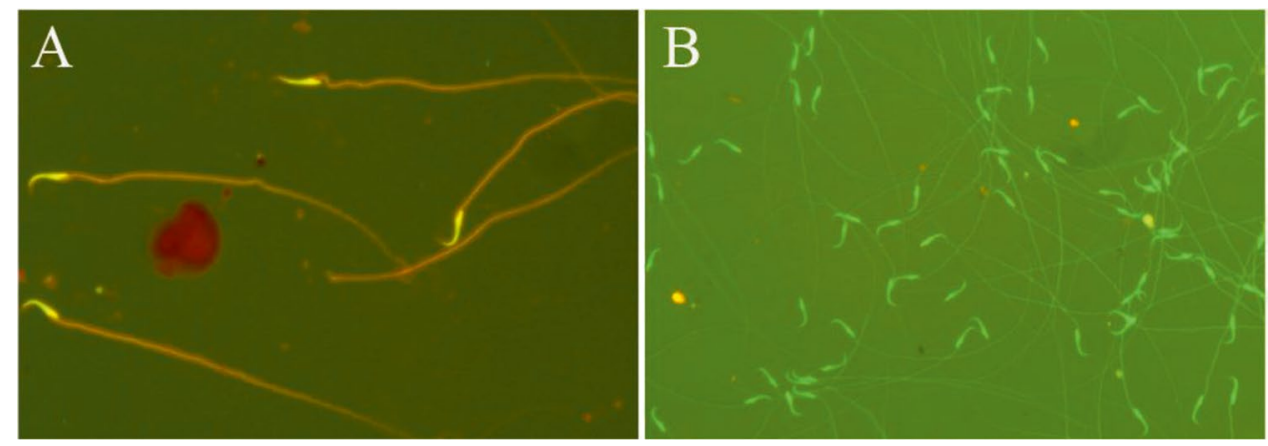
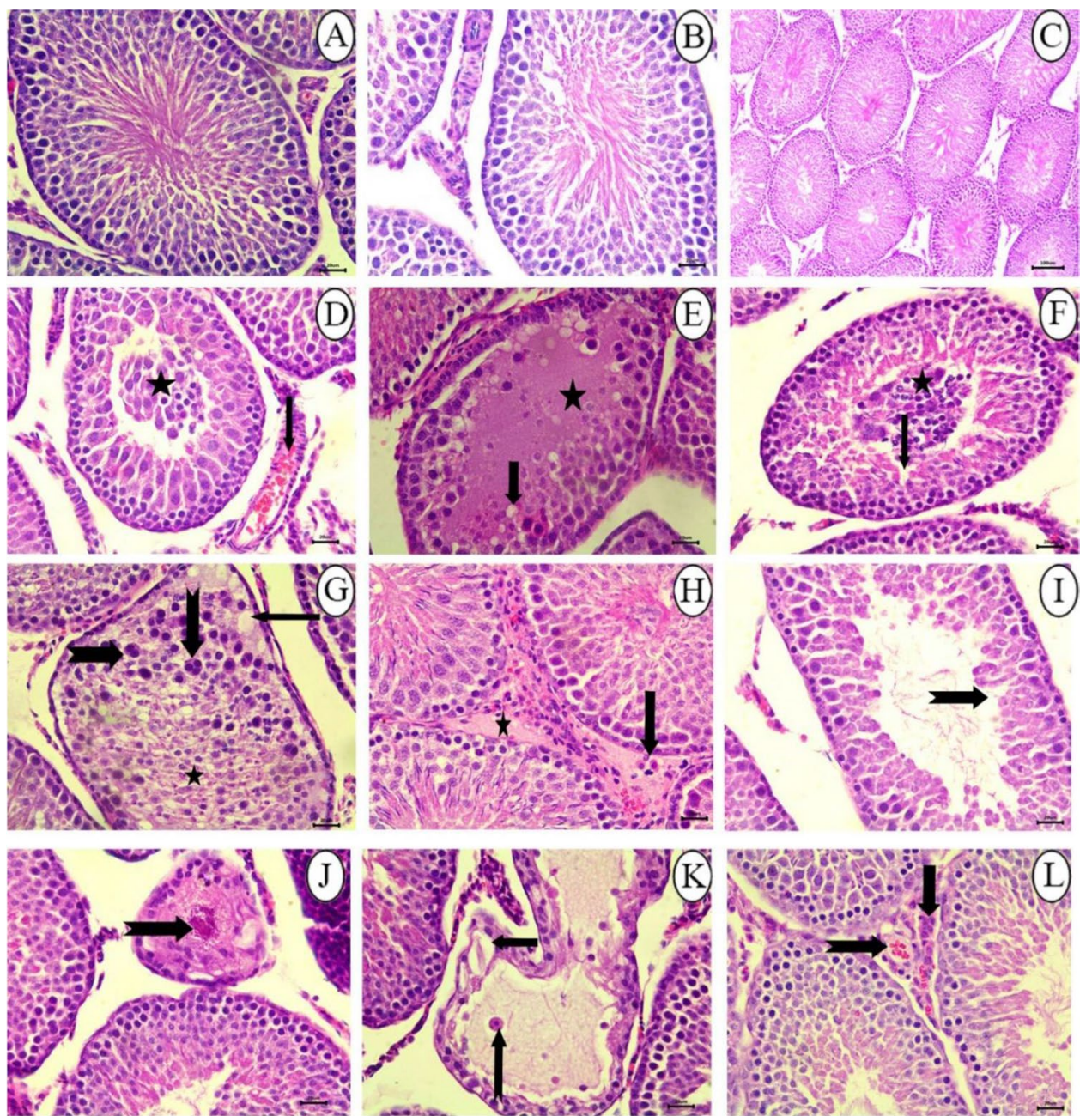

Fig. 5 Histopathological examination of testes in (A and $\mathbf{B})$ control group showing seminiferous tubules lined by normal germinal epithelium, bar $=20 \mu \mathrm{m}$; (C) control group showing seminiferous tubules, bar $=100 \mu \mathrm{m}$; (D) $25 \mathrm{mg} / \mathrm{kg}$ SFX-exposed group showing a collection of tissue debris inside the lumen of seminiferous tubules (star) and hyperemia (arrow), bar $=20 \mu \mathrm{m}$; (E) $25 \mathrm{mg} / \mathrm{kg}$ SFX-exposed group showing necrosis of germinal epithelium (arrow) and lumen filled with oedematous fluid (star), bar $=20 \mu \mathrm{m} ;(\mathbf{F}) 100 \mathrm{mg} / \mathrm{kg}$ SFX-exposed group showing (spermatid giant cells) (star), degeneration of germinal epithelium (arrow), bar $=20 \mu \mathrm{m}$; (G) $100 \mathrm{mg}$ / $\mathrm{kg}$ SFX-exposed group showing hypereosinophilic disorganized cells (star), vacuolation (arrow), and formation of (spermatid giant cells) (notched arrow), bar=20; (H) $100 \mathrm{mg} / \mathrm{kg}$ SFX-exposed group showing interstitial oedema (star) with mild hyperplasia of (Leydig cells) (arrow), bar $=20 \mu \mathrm{m}$; (I) $100 \mathrm{mg} / \mathrm{kg} \mathrm{SFX-induced} \mathrm{group} \mathrm{show-}$ ing necrosis of germinal epithelium (notched arrows), bar $=20 \mu \mathrm{m}$; (J) $500 \mathrm{mg} / \mathrm{kg}$ SFX-induced group showing coagulative necrosis in germinal epithelium (notched arrow), bar $=20 \mu \mathrm{m} ;(\mathbf{K}) 500 \mathrm{mg} /$ $\mathrm{kg}$ SFX-exposed group showing detachment of germinal epithelium (arrow) with the presence of eosinophilic fluid in the lumen of seminiferous tubules (star) and multinucleated giant cells (notched arrow), bar =20; and (L) $500 \mathrm{mg} / \mathrm{kg}$ SFX-exposed group showing congestion of interstitial blood vessels (notched arrow) and hyperplasia of (Leydig cells) (arrow), bar $=20 \mu \mathrm{m}, \mathrm{H} \& \mathrm{E}$ 
Table 5 Incidence of histopathological lesions in testis, epididymis, and seminal vesicle of the experimental groups

\begin{tabular}{|c|c|c|c|c|}
\hline Lesions & Control & $25 \mathrm{mg} / \mathrm{kg} \mathrm{SFX}$ & $100 \mathrm{mg} / \mathrm{kg} \mathrm{SFX}$ & $500 \mathrm{mg} / \mathrm{kg} \mathrm{SFX}$ \\
\hline \multicolumn{5}{|l|}{ Testis: } \\
\hline Congestion & $\begin{array}{l}- \\
(100 \%)\end{array}$ & $\begin{array}{l}++ \\
(50 \%)\end{array}$ & $\begin{array}{c}+++ \\
(75 \%)\end{array}$ & $\begin{array}{l}++++ \\
(100 \%)\end{array}$ \\
\hline Interstitial edema & $\begin{array}{l}- \\
(100 \%)\end{array}$ & $\begin{array}{l}++ \\
(75 \%)\end{array}$ & $\begin{array}{c}+++ \\
(75 \%)\end{array}$ & $\begin{array}{l}++++ \\
(100 \%)\end{array}$ \\
\hline Leydig cells hyperplasia & $\begin{array}{l}- \\
(100 \%)\end{array}$ & $\begin{array}{l}- \\
(100 \%)\end{array}$ & $\begin{array}{l}++ \\
(25 \%)\end{array}$ & $\begin{array}{l}++ \\
(50 \%)\end{array}$ \\
\hline Degeneration and necrosis of seminiferous tubules & $\begin{array}{l}- \\
(100 \%)\end{array}$ & $\begin{array}{l}+++ \\
(25 \%)\end{array}$ & $\begin{array}{l}++++ \\
(50 \%)\end{array}$ & $\begin{array}{l}++++ \\
(75 \%)\end{array}$ \\
\hline Intratubular giant cell formation & $\begin{array}{l}- \\
(100 \%)\end{array}$ & $\begin{array}{l}+++ \\
(25 \%)\end{array}$ & $\begin{array}{l}++++ \\
(50 \%)\end{array}$ & $\begin{array}{l}++++ \\
(75 \%)\end{array}$ \\
\hline \multicolumn{5}{|l|}{ Epididymis: } \\
\hline Congestion & $\begin{array}{l}- \\
(100 \%)\end{array}$ & $\begin{array}{l}++ \\
(50 \%)\end{array}$ & $\begin{array}{c}+++ \\
(75 \%)\end{array}$ & $\begin{array}{l}++ \\
(100 \%)\end{array}$ \\
\hline Interstitial C.T. proliferation & $\begin{array}{l}- \\
(100 \%)\end{array}$ & $\begin{array}{l}++ \\
(25 \%)\end{array}$ & $\begin{array}{l}+++ \\
(25 \%)\end{array}$ & $\begin{array}{l}+++ \\
(50 \%)\end{array}$ \\
\hline Hyperplasia of lining cells & $\begin{array}{l}- \\
(100 \%)\end{array}$ & $\begin{array}{l}- \\
(25 \%)\end{array}$ & $\begin{array}{l}++ \\
(50 \%)\end{array}$ & $\begin{array}{l}++ \\
(50 \%)\end{array}$ \\
\hline Intratubular giant cell formation & $\begin{array}{l}- \\
(100 \%)\end{array}$ & $\begin{array}{l}- \\
(100 \%)\end{array}$ & $\begin{array}{l}- \\
(100 \%)\end{array}$ & $\begin{array}{l}++ \\
(25 \%)\end{array}$ \\
\hline Disappearance of sperms in the lumen of epididymal ducts & $\begin{array}{l}- \\
(100 \%)\end{array}$ & $\begin{array}{l}+ \\
(25 \%)\end{array}$ & $\begin{array}{l}++ \\
(50 \%)\end{array}$ & $\begin{array}{l}+++ \\
(25 \%)\end{array}$ \\
\hline \multicolumn{5}{|l|}{ Seminal vesicle: } \\
\hline Degeneration and sloughing of the lining epithelium & $\begin{array}{l}- \\
(100 \%)\end{array}$ & $\begin{array}{l}+ \\
(25 \%)\end{array}$ & $\begin{array}{l}+ \\
(25 \%)\end{array}$ & $\begin{array}{l}+ \\
(25 \%)\end{array}$ \\
\hline Hyperplasia of lining cells & $\begin{array}{l}- \\
(100 \%)\end{array}$ & $\begin{array}{l}+ \\
(25 \%)\end{array}$ & $\begin{array}{l}+ \\
(25 \%)\end{array}$ & $\begin{array}{l}++ \\
(50 \%)\end{array}$ \\
\hline Atrophy of seminal vesicles & $\begin{array}{l}- \\
(100 \%)\end{array}$ & $\begin{array}{l}- \\
(100 \%)\end{array}$ & $\begin{array}{l}+ \\
(25 \%)\end{array}$ & $\begin{array}{l}++ \\
(50 \%)\end{array}$ \\
\hline Hemorrhage & $\begin{array}{l}- \\
(100 \%)\end{array}$ & $\begin{array}{l}- \\
(100 \%)\end{array}$ & $\begin{array}{l}+ \\
(25 \%)\end{array}$ & $\begin{array}{l}+ \\
(25 \%)\end{array}$ \\
\hline
\end{tabular}

- no lesions; + slight lesions; ++ moderate lesions; +++ severe lesions; ++++ very severe lesions. Percentages represent the no. of affected rats in each group

changes were expressed by hyperplasia of lining epithelium (Fig. 7A). Exposure to $500 \mathrm{mg} / \mathrm{kg} \mathrm{SFX}$ induced complete decrease of sperms in epididymal lumen (Fig. 7B). Complete absence of sperms in some epididymal ducts while others complete necrosed accompanied with an accumulation of spermatid giant cells inside most of the epididymal ducts were the most detectable lesions in this group (Fig. 7C, D).

The seminal vesicles of control rats were normal in architecture. The walls of seminal vesicles were folded mucosa lined with secretory epithelium (Fig. 8A\&B). Degeneration and sloughing of the lining epithelium of seminal vesicles were the most noticeable lesions in the $25 \mathrm{mg} / \mathrm{kg}$ SFX-intoxicated group (Fig. 8C). While in other seminal vesicles, there was focal hyperplasia of lining epithelium (Fig. 8D). Atrophy of seminal vesicles was a distinctive feature, predominated in $25 \%$ of examined rats in the $100 \mathrm{mg} /$ $\mathrm{kg}$ SFX-intoxicated group. Atrophy of seminal vesicles tends to appear microscopically as a decrease in the size of glandular components with increased prominence of the contracted fibromuscular stroma accompanied by hyperplasia of glandular epithelium forming small papillary folds in the glandular lumen (Fig. 9A, B). In the $500 \mathrm{mg} / \mathrm{kg} \mathrm{SFX-}$ exposed group, hyperplasia of lining epithelium associated with interstitial connective tissue proliferation in lamina propria with focal areas of hemorrhage were observed in the $50 \%$ of examined rats (Fig. 9C).

\section{Discussion}

Previous reports mentioned that the use of neonicotinoids has several toxicity outcomes such as neurotoxicity, hepatotoxicity immunotoxicity, and nephrotoxicity in both vertebrates and invertebrates (Han et al. 2021). Despite the current evidence that demonstrated different hazards for SFX 
Fig. 6 Histopathological examination of epididymis in (A) control group showing normal epididymal convoluted tubule lined with pseudostratified columnar epithelium bar $=20 \mu \mathrm{m}$; (B) control group showing epididymal ducts in, bar $=100 \mu \mathrm{m}$; (C) $25 \mathrm{mg} / \mathrm{kg}$ SFX-exposed group showing decrease in number of sperms inside the epididymal ducts (star), bar $=100 \mu \mathrm{m}$; and (D) $25 \mathrm{mg} / \mathrm{kg}$ SFX-exposed group showing hyperemia (arrow), proliferation of interstitial connective tissue (star), bar $=20 \mu \mathrm{m}, \mathrm{H} \& \mathrm{E}$
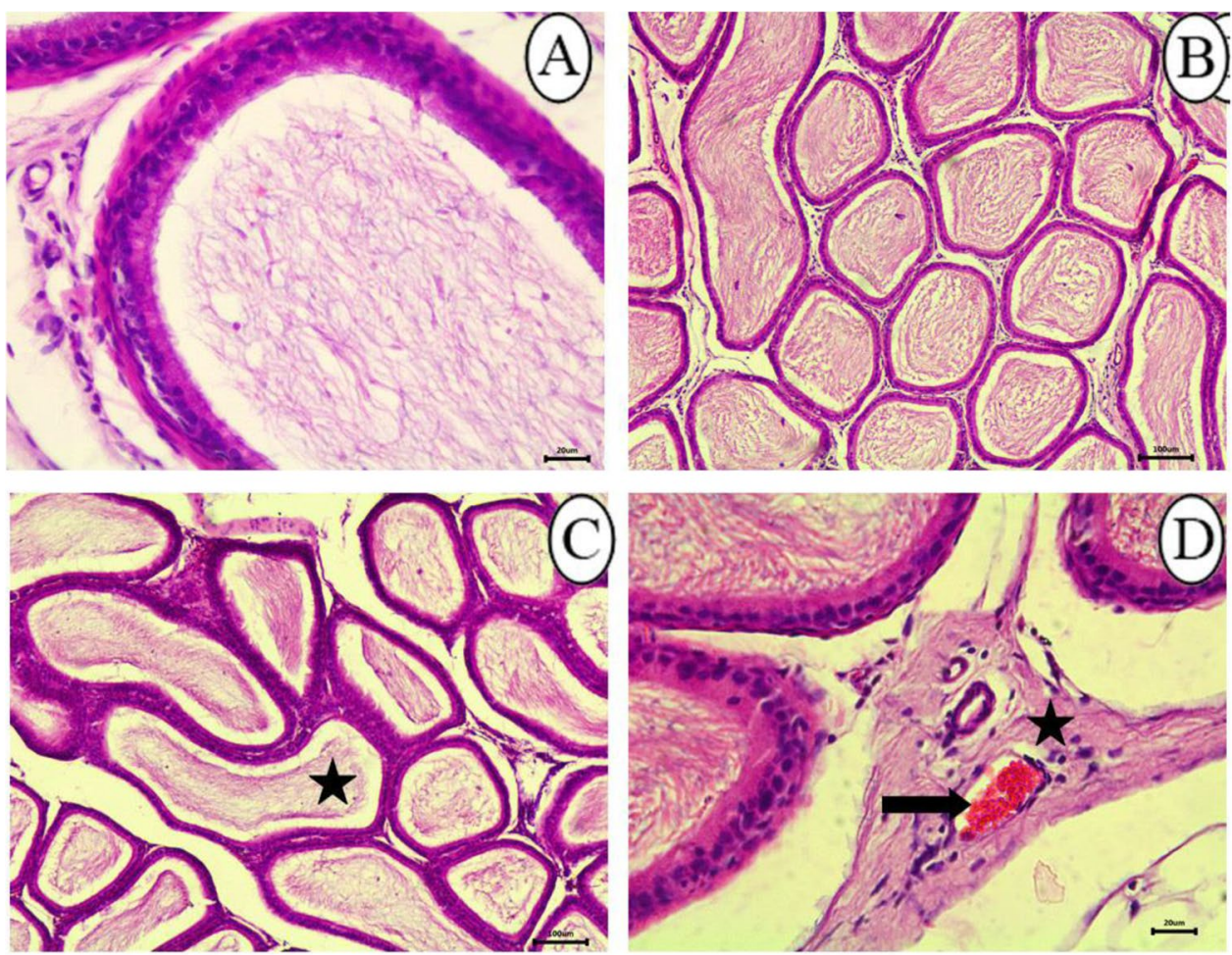

Fig. 7 Histopathological examination of epididymis in (A) $100 \mathrm{mg} / \mathrm{kg}$ SFX-exposed group showing hyperplasia of lining epithelium (notched arrow), bar $=20 \mu \mathrm{m}$; (B) $100 \mathrm{mg} / \mathrm{kg}$ SFX-exposed group showing that the most of epididymal ducts were devoid from spermatozoa (star), bar $=20 \mu \mathrm{m}$; (C) $500 \mathrm{mg} / \mathrm{kg} \mathrm{SFX}$-exposed group showing accumulation of (spermatid giant cells) (star), epididymal duct completely free from spermatozoa (notched arrow), and complete necrosis of epididymal duct (arrow), bar $=100 \mu \mathrm{m}$; and (D) $500 \mathrm{mg}$ / kg SFX-exposed group showing accumulation of (spermatid giant cells) (notched arrow); bar $=20 \mu \mathrm{m}, \mathrm{H} \& \mathrm{E}$
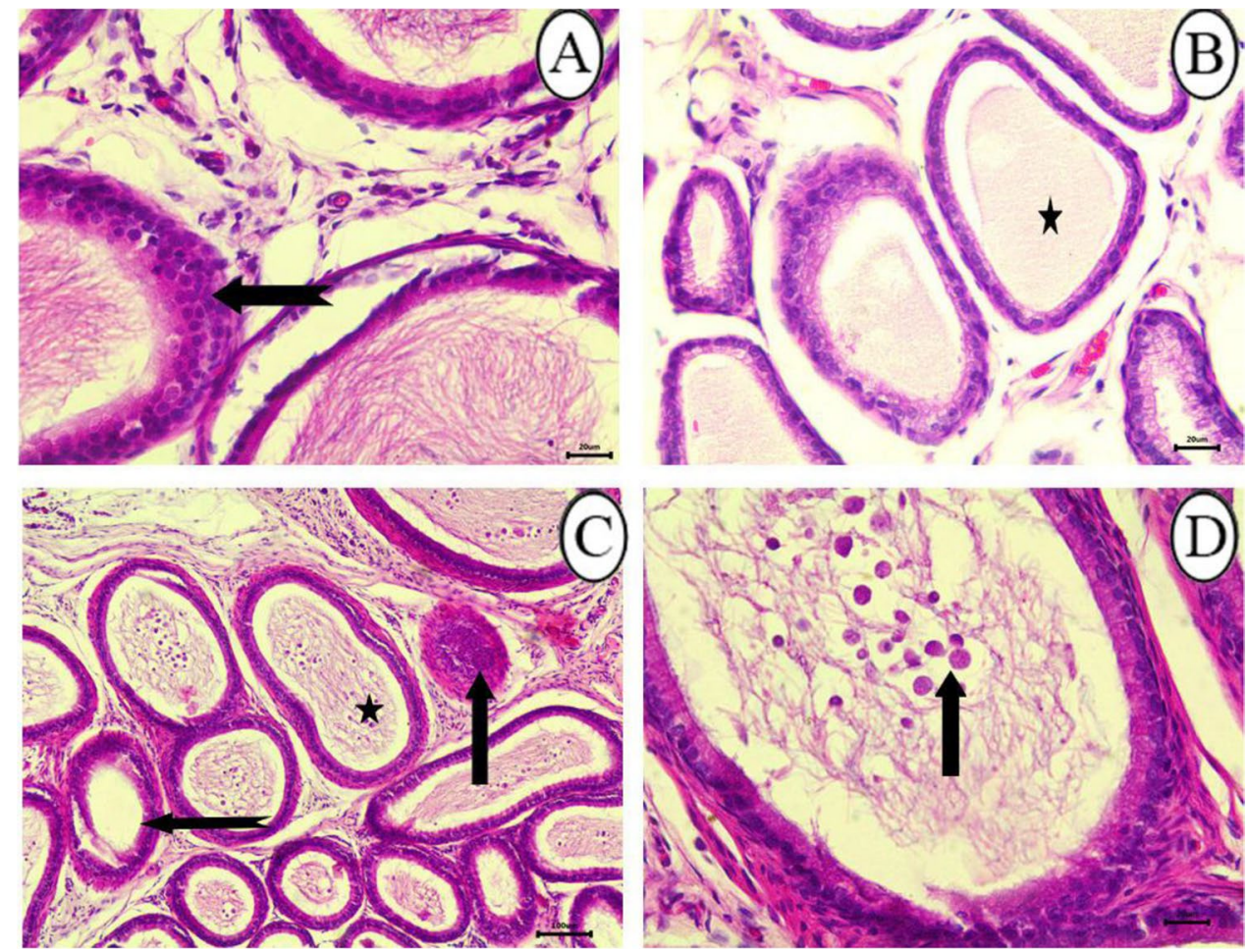

application, its potential impact on the male reproductive system remains unclear.

In the current study, exposure of rats to $500 \mathrm{mg} / \mathrm{kg} \mathrm{SFX}$ for 4 weeks lead to a significant increase in FSH level in comparison with the control and $25 \mathrm{mg} / \mathrm{kg}$ dose groups, while LH level revealed a significant increase at $100 \mathrm{mg} / \mathrm{kg}$ group and $500 \mathrm{mg} / \mathrm{kg}$ SFX dose groups as compared with the control group. This is in agreement with Saber et al. (2021) who showed that exposure of male rats to imidacloprid at a dose of $22.5 \mathrm{mg} / \mathrm{kg}$ every day for 56 days caused an increase 


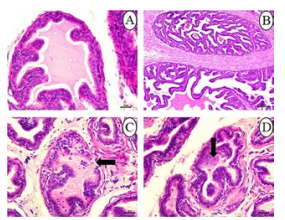

Fig. 8 Histopathological examination of seminal vesicles in (A) control group showing folded mucosa lined with secretory epithelium, bar $=20 \mu \mathrm{m}$; (B) the seminal vesicles in control group, bar $=100 \mu \mathrm{m}$; (C) $25 \mathrm{mg} / \mathrm{kg} \mathrm{SFX}$-exposed group showing degeneration and slough- ing of lining epithelium (arrow), bar $=20 \mu \mathrm{m}$; (D) $25 \mathrm{mg} / \mathrm{kg}$ SFXexposed group showing hyperplasia of lining epithelium (arrows), bar $=20 \mu \mathrm{m}, \mathrm{H} \& \mathrm{E}$

Fig. 9 Histopathological examination of seminal vesicles in (A) $100 \mathrm{mg} / \mathrm{kg}$ SFX-exposed group showing papillary structure extending into the glandular lumen (arrow), bar $=20 \mu \mathrm{m}$; (B) $100 \mathrm{mg} / \mathrm{kg}$ SFX-induced group showing increased prominence of the contracted fibromuscular stroma (arrow), bar $=100 \mu \mathrm{m}$; (C) $500 \mathrm{mg} / \mathrm{kg}$ SFX-exposed group showing hyperplasia of lining epithelium (arrow), connective tissue proliferation in lamina propria (star), and hemorrhage (notched arrow), bar $=20 \mu \mathrm{m}, \mathrm{H} \& \mathrm{E}$
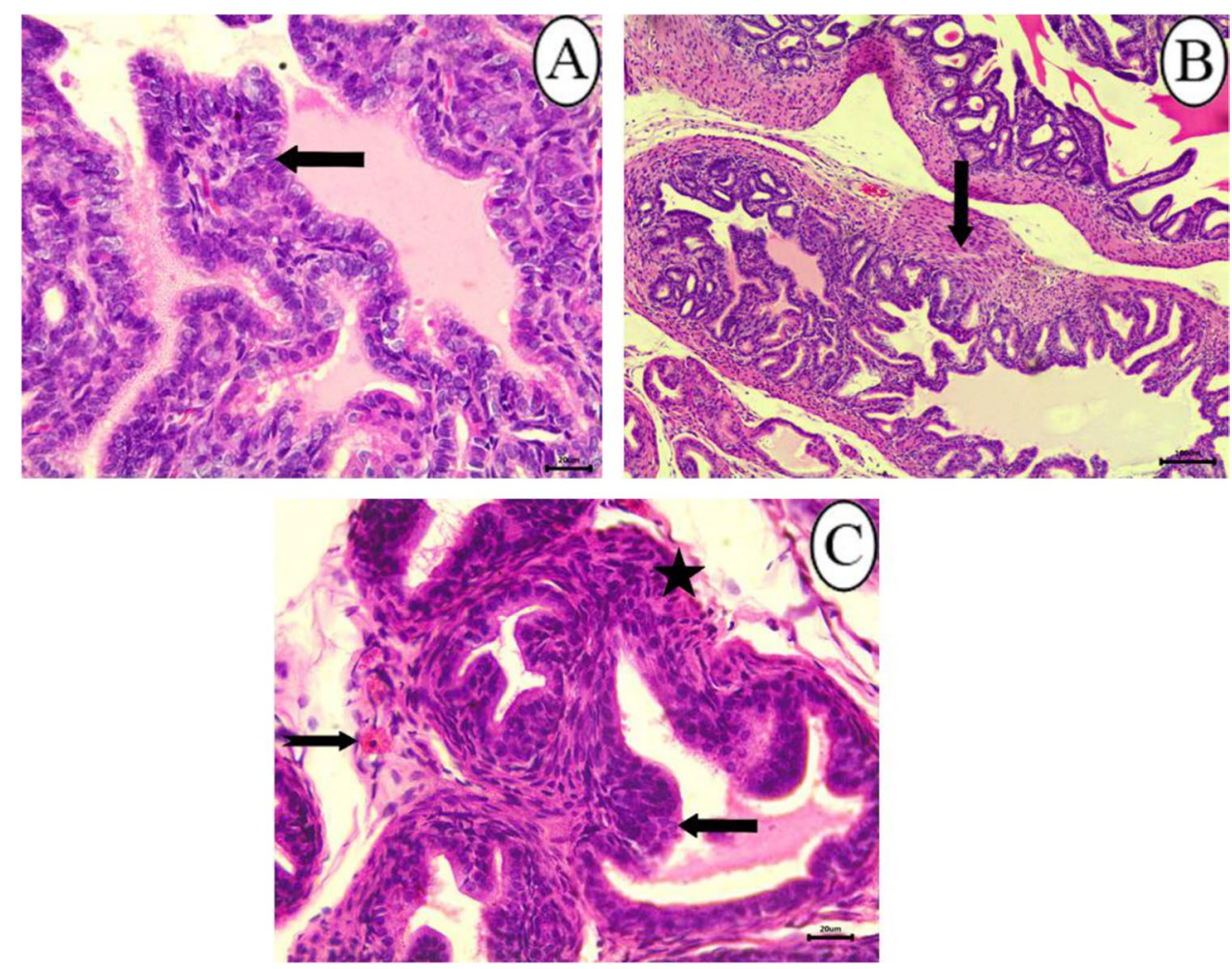

in the levels of LH and FSH compared to the control group. Similarly, another study conducted on exposure of the rats to acetamiprid with low $(12.5 \mathrm{mg} / \mathrm{kg})$, medium $(25 \mathrm{mg} / \mathrm{kg})$, or high dose $(35 \mathrm{mg} / \mathrm{kg})$ for 90 days caused an increment of serum levels of FSH and LH in low- and medium-dose groups (Arican et al. 2020).

A similar study investigated the effects of the most common insecticides used in Nigeria on the reproductive hormones of male rats and found that the insecticides caused an increase in FSH levels compared to control rats (Airaodion et al. 2019). Regulation of spermatogenesis in the testes occurs at the hypothalamic-pituitary-testicular axis. Gonadotropin-releasing hormone $(\mathrm{GnRH})$ stimulates gonadotropin cells to secrete LH and FSH. GnRH release is regulated by testosterone through a negative feedback loop. Luteinizing hormone stimulates Leydig cells to produce testosterone and FSH stimulates Sertoli cells to produce androgen-binding protein (ABP). Androgen-binding protein binds to testosterone to enhance meiosis of the spermatocytes (Zhou et al. 2019). In the current study, the high-serum measure of gonadotrophins with exposure to SFX prompted to suppression of feed-back inhibition of the anterior pituitary. The suppression of feedback inhibition may lead to an increase the LH and FSH secretion (Zhou et al. 2019). These results indicated that SFX has a direct effect on the pituitary, which leads to an increase in circulating LH levels. The results obtained for serum FSH and LH levels after exposure to SFX with different doses agree with the findings of Darbre (2018) who reported that air pollution has a serious effect on hormones, because many environmental pollutant chemicals can interfere with the function of the endocrine system, which are called endocrine disrupting chemicals. However, the exact mechanism of how these chemicals affect hormones is still unclear. In the present study, the level of MDA in rats 
significantly increased in all SFX-exposed groups as compared with the control group. Also, GPx activity indicated a significant increase in 100 and $500 \mathrm{mg} / \mathrm{kg}$ dose groups as compared with the control group and $25 \mathrm{mg} / \mathrm{kg}$ dose group. This coincides with Fathy and Abdelkader (2021b) who noticed a significant dose-dependent increment of MDA level in the spleen of SFX-treated groups as compared with the control group. Sahinoz et al. (2019) has also previously shown that chlorpyrifos insecticide exposure increased the production of free radicals and induced oxidative stress. A previous study evaluated the biochemical effect of gestational exposure to four pesticides on female Wistar rats and their offspring at adult age and indicated that MDA levels were significantly higher in pesticide-exposed rats compared to the control group (Ndonwi et al. 2019). Malondialdehyde (MDA) is a major oxidation product of polyunsaturated fatty acids and increased MDA content is a critical indicator of lipid peroxidation. In our study, the MDA level increased in SFX-treated rats. It may be proposed that increment of the MDA level can be an indicator of SXF lipoperoxidative injury. Also, another study that investigated the acute toxicity of pesticides as profenofos, cyhalothrin, and azadirachtin showed that GPx depicted an initial increment followed by a subsequent reduction (Chatterjee et al. 2021). Similarly, Piner Benli and Çelik (2021a) described that GPx activity and MDA level increased in sulfoxaflor-treated group compared to the control group. In our study, activity of GPx increased in SFX-exposed rats. The increase in GPx activity may be due to an increase in the production of reactive oxygen species in SFX toxicity.

Hormonal regulation of the male reproductive system can be altered by the imbalance between the production of reactive oxygen species and the antioxidant defense mechanisms. An increase in the generation of reactive oxygen species may damage reproductive tissues or intervene with the hypothalamic-pituitary gonadal axis and its connections with other endocrine axis and badly affect male reproductive function, thus inducing infertility in males (Darbandi et al. 2018). From their study, the generation of reactive oxygen species caused activation of the hypothalamic-pituitary axis and released cortisol (in humans) in response to stress. These stress hormones adversely affect LH secretion from the anterior pituitary. Therefore, the adverse impact of SFX on male sex hormones in this study could be attributed to the production of free radicals and the induction of oxidative stress.

In our study, the percentage of dead and abnormal epididymal sperm showed a significant increase in all SFXexposed groups as compared with the control group. The percentage of DNA damage in sperms of rats after exposure to SFX at $500 \mathrm{mg} / \mathrm{kg}$ for 4 weeks also indicated a significant increase in comparison with the control, 25 , and $100 \mathrm{mg} / \mathrm{kg}$ dose groups. This is in tandem with another study which also observed that rats had lower sperm counts after 45 days of acetamiprid and these rats revealed a significant decrease in sperm motility and increased rates of abnormal morphology (Mosbah et al. 2018). Exposure to neonicotinoid insecticides as acetamiprid at $26.67,40$, and $80 \mathrm{mg} / \mathrm{kg}$ body weight for 90 days leads to a significant reduction in sperm motility and count of epididymal sperm and a significant increment in the rate of abnormal sperms when compared to the control group (Kenfack et al. 2018). However, Quinalphos exposure at $1.0 \mathrm{mg} / \mathrm{kg}$ resulted in a significant reduction in motility and increment in sperm head defects and DNA damage (Kumari et al. 2021). Pesticides including SFX induce oxidative stress led to imbalance of antioxidant defense system (Bhardwaj et al. 2018). In this study, the increased level of MDA in serum indicates that SFX caused oxidative stress. Elevated oxidative stress induced sever changes in the epididymis and maturing spermatozoa that result in the impairment of sperm quality (Wu et al. 2020). Moreover, oxidative damages in sperms are associated with immobility, reduced fertilization rate, DNA damage, and high frequency of sperm apoptosis (Mehraban et al. 2019). In the current study, an increment in abnormal sperm morphology and DNA damage observed after 4 weeks after SXF administration revealed that SFX has more adverse effects on male reproductive tissue. Furthermore, another way SFX affects the function of the male reproductive system is to damage DNA (Said et al. 2021), since the morphology of sperm is organized by various autosomal and Y-specific genes (Bansal et al. 2017).

Histopathological investigation of testes in $25 \mathrm{mg} / \mathrm{kg}$ SFX-intoxicated group showed testicular degeneration and a decrease in the number of layers that appeared in a small number of seminiferous tubules with dilatation of seminiferous tubules filled with eosinophilic fluid. The testicular damage was increased in the rats intoxicated with $100 \mathrm{mg} / \mathrm{kg}$ SFX which was characterized by testicular degeneration that appeared in most of the seminiferous tubules, dilatation of seminiferous tubules accompanied with hypereosinophilic disorganized vacuolated cells. Additionally, interstitial edema with mild hyperplasia of Leydig cells was also seen. The same alterations were seen in animals treated with $500 \mathrm{mg} / \mathrm{kg}$ SFX but became more obvious described as severe coagulative necrosis in the cells of lining layers in the seminiferous tubules. Similar results described by Zakzook et al. (2020) who reported on the effect of dimethoate in testes characterized by degeneration, necrosis, and loss of spermatogenic cell layer associated with Sertoli cell vacuolation and severe interstitial edema. Hyperplasia of Leydig cells in both $100 \mathrm{mg} / \mathrm{kg}$ SFX-exposed group and $500 \mathrm{mg} / \mathrm{kg}$ SFX-exposed group explain the increase in the testosterone hormone in these groups. Concerning histopathological observations of epididymis was expressed as the proliferation of interstitial connective tissue infiltrated with inflammatory cells with congestion of intertubular blood vessels in all intoxicated 
groups. The epididymal damage became more evident in the epididymis of $500 \mathrm{mg} / \mathrm{kg}$ SFX-exposed rats which was characterized by the accumulation of spermatid giant cells with a decrease in sperm concentration in the epididymal lumen. These results agree with the results appeared in the study used mixture of the pesticides (cypermethrin, mancozeb, and metalaxyl); pesticides revealed decrease epididymis mass by reducing sperm concentration and the degenerative change in epididymal tissues (Bouabdallah et al. 2022) According to Ali and Ibrahim (2018), the harmful effects of some pesticides on reproductive system of may be due to its electrophilic attack on their cells. Degeneration of lining epithelium of seminal vesicles was observed in the $25 \mathrm{mg} / \mathrm{kg} \mathrm{SFX}$-intoxicated group. Seminal vesicles completely atrophied in the $100 \mathrm{mg} / \mathrm{kg}$ SFX-intoxicated group in some cases. Damage to accessory organs could be attributed due to a significant increase in MDA and GPx levels, while focal areas of hyperplasia of lining epithelium in other seminal vesicles may be related to an increase of testosterone level (Creasy et al. 2012).

\section{Conclusion}

Sulfoxaflor induced biochemical changes in FSH, LH, MDA, and GPx in serum of rats. Also, sulfoxaflor increased dead and abnormal sperm percentage and caused DNA damage in sperms of rats in comparison with the control group. Histopathological examination of testes showed testicular degeneration with severe coagulative necrosis while epididymis revealed the proliferation of interstitial connective tissue infiltrated with inflammatory cells with congestion of intertubular blood vessels as well as degeneration of lining epithelium of seminal vesicles.

\begin{abstract}
Author contribution (1) Dr/Wafaa Hasanien contributed in practical part, data analysis, and writing of manuscript. (2) Dr/Marwa Farouk contributed in the design of the study and collection, analysis, and writing the manuscript. (3) Dr/Doha Yahia contributed in the design of the study and collection, analysis, and interpretations and writing the manuscript. (4) Dr/Hassan A. Hussein contributed in practical part, data analysis, and writing of manuscript.
\end{abstract}

Funding Open access funding provided by The Science, Technology \& Innovation Funding Authority (STDF) in cooperation with The Egyptian Knowledge Bank (EKB).

Data availability Applicable.

\section{Declarations}

Ethics approval and consent to participate Applicable.
Consent for publication Not applicable.

Competing interests The authors declare no competing interests.

Open Access This article is licensed under a Creative Commons Attribution 4.0 International License, which permits use, sharing, adaptation, distribution and reproduction in any medium or format, as long as you give appropriate credit to the original author(s) and the source, provide a link to the Creative Commons licence, and indicate if changes were made. The images or other third party material in this article are included in the article's Creative Commons licence, unless indicated otherwise in a credit line to the material. If material is not included in the article's Creative Commons licence and your intended use is not permitted by statutory regulation or exceeds the permitted use, you will need to obtain permission directly from the copyright holder. To view a copy of this licence, visit http://creativecommons.org/licenses/by/4.0/.

\section{References}

Airaodion AI, Ngwogu AC, Megwas AU, Ekenjoku JA, Ngwogu KO (2019) Effect of common household insecticides used in Nigeria on rat male reproductive hormones. Int J Res Rep in Gynaecol 2(1):1-8

Ali RI, Ibrahim MA (2018) Malathion induced testicular toxicity and oxidative damage in male mice: the protective effect of curcumin. Egypt J Forensic Sci 8:1-13

Arıcan EY, Kayalı DG, Karaca BU, Boran T, Öztürk N, Okyar A, Ercan F, Özhan G (2020) Reproductive effects of subchronic exposure to acetamiprid in male rats. J Scientific Reports 10:1-10

Authority E F S, Crivellente F, Hart A, Hernandez-Jerez AF, Bennekou SH, Pedersen R, Terron A, Wolterink G, Mohimont L (2019) Establishment of cumulative assessment groups of pesticides for their effects on the nervous system. EFSA J 17(9):5800-5115

Bacci L, Convertini S, Rossaro B (2018) A review of sulfoxaflor, a derivative of biological acting substances as a class of insecticides with a broad range of action against many insect pests. J Entomol Acarol Res 50(3):7836

Bansal SK, Singh V, Singh K and Singh R (2017) Sex chromosomal genes in male infertility. Male Infertility: Understanding, Causes and Treatment. Springer, pp 253-270

Bass C, Field LM (2018) Neonicotinoids. J. Curr Biol 28:R772-R773

Beastall GH, Ferguson KM, O'reilly DST, Seth J, Sheridan B (1987) Assays for follicle stimulating hormone and luteinising hormone: guidelines for the provision of a clinical biochemistry service. Ann Clin Biocuhem 24:246-262

Bhardwaj JK, Mittal M, Saraf P, Kumari P (2018) Pesticides induced oxidative stress and female infertility: a review. J Toxin Reviews 39(1):1-13

Borenstein M, Rothstein H, Cohen J (1997) Sample power statistics 10. J SPSS Inc., Chicago

Bouabdallah N, Mallem L, Abdennour C, Chouabia A, Tektak M (2022) Toxic impacts of a mixture of three pesticides on the reproduction and oxidative stress in male rats. J Anim Behav Biometeorol 10:2204-2204

Chatterjee A, Bhattacharya R, Chatterjee S, Saha NC (2021) Acute toxicity of organophosphate pesticide profenofos, pyrethroid pesticide $\lambda$ cyhalothrin and biopesticide azadirachtin and their sublethal effects on growth and oxidative stress enzymes in benthic oligochaete worm, Tubifex tubifex. J Comp Biochem Physiol C Toxicol Pharmacol 242:108943 
Creasy D, Bube A, Rijk Ed, Kandori H, Kuwahara M, Masson R, Nolte T, Reams R, Regan K, Rehm S (2012) Proliferative and nonproliferative lesions of the rat and mouse male reproductive system. J Toxicol Pathol 40:40S-121S

Darbandi M, Darbandi G, Agarwal A, Sengupta P, Durairajanayagam D, Henkel R, Sadeghi M (2018) Effect of reactive oxygen species on sex hormones. J Reprod Biol Endocrinol 16:87

Darbre PD (2018) Overview of air pollution and endocrine disorders. Int J General Med 11:191

FAO/WHO (2003) joint FAO/WHO meeting on pesticide residues; pesticide residues in food: sulfoxaflor (946578-00-3) ): http:// www.inchem.org/pages/jmpr.html. Accessed 22 Jul 2015

Fathy SM, Abdelkader IY (2021a) Effect of resveratrol on the inflammatory status and oxidative stress in thymus gland and spleen of sulfoxaflor-treated rats. J Environ Toxicol 36:1326-1337

Fathy SM, Abdelkader IY (2021b) Effect of resveratrol on the inflammatory status and oxidative stress in thymus gland and spleen of sulfoxaflor-treated rats. J Environ Toxicol 36(7):1326-1337

Gould F, Brown ZS, Kuzma J (2018) Wicked evolution: can we address the sociobiological dilemma of pesticide resistance? J Sci 360:728-732

Hadi Chegni S, Taghizadeh M, Goliaei B (2020) A systematic review of the biophysical aspect of the effect of pesticides on the structural changes in HSA protein: the analysis of experimental and computational studies. J Arak Univ Med Sci 22:136-169

Han M-h, Fang H-j, Wang Y-p, Wang H-x, Jiang Q-w (2021) Pollution, human exposure and harmful effects of neonicotinoid pesticides. Shanghai Journal of Preventive Medicine 33(6):534-543

Kenfack A, Guiekep N, Ngoula F, Vemo BN, Bouli E, Pamo ET (2018) Reproductive toxicity of acetamiprid in male Guinea pig (Cavia porcellus). J Anim Sci Vet Med 3:105-111

Kumari S, Dcunha R, Sanghvi SP, Nayak G, Kalthur SG, Raut SY, Mutalik S, Siddiqui S, Alrumman SA, Adiga SK (2021) Organophosphorus pesticide quinalphos (Ekalux 25 EC) reduces sperm functional competence and decreases the fertilisation potential in Swiss albino mice. J Andrologia 53:e14115

Mehraban Z, Ghaffari Novin M, Golmohammadi MG, Sagha M, Pouriran K, Nazarian H (2019) Protective effect of gallic acid on apoptosis of sperm and in vitro fertilization in adult male mice treated with cyclophosphamide. J Cell Biochem 120:17250-17257

Menkveld R (2010) Clinical significance of the low normal sperm morphology value as proposed in the fifth edition of the WHO Laboratory Manual for the Examination and Processing of Human Semen. Asian J Androl 12:47

Mosbah R, Djerrou Z, Mantovani A (2018) Protective effect of Nigella sativa oil against acetamiprid induced reproductive toxicity in male rats. J Drug chemical toxicology 41:206-212

Ndonwi EN, Atogho-Tiedeu B, Lontchi-Yimagou E, Shinkafi TS, Nanfa D, Balti EV, Indusmita R, Mahmood A, Katte J-C, Mbanya A (2019) Gestational exposure to pesticides induces oxidative stress and lipid peroxidation in offspring that persist at adult age in an animal model. J Toxicol Res 35:241-248

NRC (1996) Guide for the care and use of laboratory animals. National Academy Press, Washington, pp 415-416

Ohkawa H, Ohishi N, Yagi K (1979) Assay for lipid peroxides in animal tissue by thiobarbaturic acid reaction. Anal Biochem 95:351-358

Paglia DE, Valentine WN (1967) Studies on the quantitative and qualitative characterization of erythrocyte glutathione peroxidase. $\mathrm{J}$ Lab Clin Med 70:158-169

Piner Benli P, Çelik M (2021a) Glutathione and its dependent enzymes' modulatory responses to neonicotinoid insecticide sulfoxaflor induced oxidative damage in zebrafish in vivo. J Science Progress 104:00368504211028361
Piner Benli P, Çelik M (2021b) In vivo effects of neonicotinoid-sulfoximine insecticide sulfoxaflor on acetylcholinesterase activity in the tissues of zebrafish (Danio rerio). J Toxics 9:73

Saber TM, Arisha AH, Abo-Elmaaty AM, Abdelgawad FE, Metwally MM, Saber T, Mansour MF (2021) Thymol alleviates imidacloprid-induced testicular toxicity by modulating oxidative stress and expression of steroidogenesis and apoptosis-related genes in adult male rats. J Ecotoxicol Environ Saf 221:112435

Sahinoz E, Aral F, Dogu Z, Koyuncu I, Yuksekdag O (2019) The protective effects of curcumin on organophosphate insecticide chlorpyrifos-induced oxidative stress and DNA damage in Oncorhynchus mykiss. Turkish J Fish Aquat Sci 20:185-195

Said NI, Abd-Elrazek AM, El-dash HA (2021) The protective role of resveratrol against sulfoxaflor-induced toxicity in testis of adult male rats. J Environ Toxicol 36:2105-2115

Sayed MM, Hassanein KM, Senosy W (2014) Protective effects of thymoquinone and 1-cysteine on cadmium-induced reproductive toxicity in rats. J Toxicol Rep 1:612-620

Scott RT, Toner JP, Muasher SJ, Oehninger S, Robinson S, Rosenwaks Z, sterility (1989) Follicle-stimulating hormone levels on cycle day 3 are predictive of in vitro fertilization outcome. J Fertility 51:651-654

Sparks TC, Crossthwaite AJ, Nauen R, Banba S, Cordova D, Earley F, Ebbinghaus-Kintscher U, Fujioka S, Hirao A, Karmon D (2020) Insecticides, biologics and nematicides: updates to IRAC's mode of action classification-a tool for resistance management. J Pestic Biochem Physiol 167:104587

Suvarna KS, Layton C, Bancroft JD (2018) Bancroft's theory and practice of histological techniques E-Book. Elsevier Health Sciences 40-126.

Tejada RI, Mitchell JC, Norman A, Marik JJ, Friedman S, sterility (1984) A test for the practical evaluation of male fertility by acridine orange (AO) fluorescence. J Fertility 42:87-91

Tietz NW (1995) Clinical Guide to Laboratory Tests, 3rd edn. W.B Saunders Company, Philadelphia

Watson GB, Siebert MW, Wang NX, Loso MR, Sparks TC (2021) Sulfoxaflor-A sulfoximine insecticide: review and analysis of mode of action, resistance and cross-resistance. J Pestic Biochem Physiol 178:104924

Wu PY, Scarlata E, O’Flaherty C (2020) Long-term adverse effects of oxidative stress on rat epididymis and spermatozoa. J Antioxidants 9:170

Wyrobek AJ, Gordon LA, Burkhart JG, Francis MW, Kapp RW Jr, Letz G, Malling HV, Topham JC, Whorton MD (1983) An evaluation of the mouse sperm morphology test and other sperm tests in nonhuman mammals: a report of the US Environmental Protection Agency Gene-Tox Program. J Mutat Res/Rev Genet Toxicol 115:1-72

Xu L, Guo L, Wang Z, Xu X, Zhang S, Wu X, Kuang H, Xu C (2020) Profiling and identification of biocatalyzed transformation of sulfoxaflor in vivo. J Angew Chem Int Ed 59:16218-16224

Zakzook F, Hegazy H, Yosef T, Gomaa G (2020) Thymoquinone attenuates dimethoate induced hepatic and testicular genotoxicity in rats. Kafrelsheikh Veterinary Medical J 18:25-32

Zhou R, Wu J, Liu B, Jiang Y, Chen W, Li J, He Q, He Z (2019) The roles and mechanisms of Leydig cells and myoid cells in regulating spermatogenesis. J Cell Mol Life Sci 76:2681-2695

Publisher's note Springer Nature remains neutral with regard to jurisdictional claims in published maps and institutional affiliations. 